\title{
Interpreting Accent Marks as Hiatus Indicators: Syllabification Intuitions for io Sequences in US Spanish*
}

MARY ELIZABETH BEATON**

How to cite this article: Beaton, M.E. (2020). Interpreting Accent Marks as Hiatus Indicators: Syllabification Intuitions for io Sequences in US Spanish, Cuadernos de Lingüística Hispánica (36), 235-258.

$10.19053 / 0121053 X . n 36.2020 .11431$

\section{* Research article.}

** Assistant Professor of Spanish at Denison University. Her research interests include phonetics, phonology, and sociolinguistics. She is particularly interested in stigmatized language features and communities that are subject to linguistic discrimination. Her work focuses on Spanish in the Caribbean and the United States and Brazilian Portuguese. E-mail: beatonm@denison.edu ㅇttps://orcid.org/0000-0002-4064-7939 


\section{Abstract}

This study considers the syllabification perceptions of heritage speakers of Spanish (HSS), second language learners, and monolingual speakers in words with io sequences in order to understand the differences between HSS and the other two groups. Participants completed a reading task and then a listening task in which they indicated the number of syllables in each stimulus perceived. Three different lexical stress patterns were tested: stress on $i$ (like río), stress on $o$ (like pidió), and atonic syllables (like folio). The results show that heritage participants behave like monolinguals with audio stimuli, but in the reading task they interpret orthographic accent marks as indicators that two vowels should be divided into separate syllables. This leads to accurate interpretations of stimuli with stress on $i$, since Spanish phonology dictates that stressed high vowels are syllabified in hiatus. Atonic syllables, which lack an orthographic accent, are correctly syllabified as diphthongs. However, heritage participants were less accurate with stress on $o$ because they treated these stimuli like those with stress on $i$. These findings have implications for both linguistic theory and for pedagogy.

Keywords: heritage Spanish, bilingualism, heritage phonology, syllabification, Spanish in the United States, diphthongs, hiatus, vowel sequences, accent marks, heritage writing.

\section{Interpretación de los acentos ortográficos como indicadores de hiato}

\section{Resumen}

Este estudio examina las percepciones silábicas de los hablantes de herencia $(\mathrm{HH})$, los aprendientes de segunda lengua y los hablantes monolingües en las palabras con secuencias vocálicas io, con el fin de entender las diferencias entre las intuiciones de los hablantes de herencia y las otros dos grupos. Los participantes completaron una actividad lectora y después, una actividad auditiva, en las que indicaron el número de sílabas que percibían en cada estímulo. Se examinaron tres patrones de acentuación léxica: $i$ acentuada (como río), o acentuada (como pidió) y sílabas atónicas (comofolio). Los resultados muestran que los HH se comportan como los hablantes monolingües ante los estímulos auditivos, pero en la tarea lectora interpretan las tildes como indicadores de hiato. Es decir, ante las secuencias con una tilde, los HH separaron las dos vocales en dos sílabas distintas. Este comportamiento lleva a interpretaciones acertadas ante estímulos con $i$ acentuada, ya que la fonología del español exige que las vocales altas acentuadas se silabifiquen en hiato. Los HH también acertaron con las sílabas atónicas, las que carecen de una tilde. Sin embargo, estos mismos participantes tuvieron menos éxito con 
las palabras con $o$ acentuada porque trataron estos estímulos como los estímulos con $i$ acentuada. Estos resultados tienen implicaciones tanto para la teoría lingüística como para la pedagogía.

Palabras clave: español de herencia, bilingüismo, fonología de herencia, silabificación, español en los Estados Unidos, diptongo, hiato, secuencias vocálicas, signos de acentuación, escritura de herencia.

\section{Interprétation des accents d'orthographe comme indicateurs de hiatus}

\section{Résumé}

Cette étude examine les perceptions syllabiques des locuteurs d' héritage (LH), des apprenants de langue seconde et des locuteurs monolingues dans des mots avec des séquences de voyelles io, afin de comprendre les différences entre les intuitions des locuteurs d' héritage et les autres. deux groupes, et de quelle manière elles se comparent à celles des autres deux groupes. Les participants ont achevé une activité de lecture, puis une activité d'écoute dans laquelle ils ont indiqué le nombre de syllabes qu'ils ont perçues dans chaque stimulus. Trois schémas de contrainte lexicale ont été examinés; 1 accentué (comme la rivière), ou accentué (comme demandé) et des syllabes atoniques (comme folio). Les résultats montrent que les LH se comportent comme des locuteurs monolingues face à des stimulus auditifs, mais dans l'activité de lecture, ils interprètent les accents comme des indicateurs de hiatus. Autrement dit, avant les séquences avec un accent d'orthographe, le LH a séparé les deux voyelles en deux syllabes différentes. Ce comportement conduit à des interprétations correctes face à des stimulus avec un ia accentué, étant donné que la phonologie espagnole exige que les voyelles hautes accentuées se syllabifiquent en hiatus. Les LH ont également identifié correctement les syllabes atonnes, qui n'ont pas d'accent d'ortographe. Cependant, ces mêmes participants ont eu moins de succès avec les mots avec un 0 accentué parce qu'ils l'ont considéré comme étant un i accentué. Ces résultats ont des implications à la fois pour la théorie linguistique que pour la pédagogie.

Mots-clés: espagnol d' héritage, bilinguisme, phonologie d' héritage, syllabification, espagnol aux États-Unis, diphtongues, hiatus, séquences de voyelles, marques d'accentuation, écriture 


\section{Interpretação de acentes ortográficos como indicadores de hiato}

\section{Resumo}

Este estudo examina as percepções silábicas de falantes de patrimônio (FP), aprendizes da segunda língua e falantes monolíngues de palavras com sequências de vogais io, a fim de entender as diferenças entre as intuições de falantes de patrimônio e outros dois grupos. como as intuições dos falantes de herança se comparam com as dos outros dois grupos. Os participantes concluíram uma atividade de leitura, depois uma atividade de escuta, na qual indicaram o número de sílabas que perceberam em cada estímulo. Três padrões de acentuação lexical foram examinados; í acentuado (como rio), ó acentuada (tal como solicitado) e sílabas átonas (como folio). Os resultados mostram que os FP se comportam como falantes monolíngues diante de estímulos auditivos, mas na tarefa de leitura interpretam os acentos como indicadores de hiato. Ou seja, antes das sequências com um til, os FP separava as duas vogais em duas sílabas diferentes. Esse comportamento leva a interpretações corretas dos estímulos com um i acentuado, uma vez que a fonologia espanhola exige que as vogais altas acentuadas sejam sílabas no hiato. Os FP também estavam corretos com as sílabas atônicas, que não têm um til. No entanto, esses mesmos participantes tiveram menos sucesso com as palavras com ou acentuados e trataram esses estímulos como estímulos com um acentuado i. Esses resultados têm implicações para a teoria linguística e a pedagogia.

Palavras-chave: espanhol patrimonial, bilinguismo, fonologia patrimonial, silabificação, espanhol nos Estados Unidos, ditongos, hiato, sequências de vogais, acentos, escritos patrimoniais 


\section{Introduction}

The Latino population in the United States was 58.9 million - 18\% of the total population - as of July 2017 (U.S. Census Bureau, 2018). This population is growing, but the percentage of this population who are immigrants continues to decline. In 2000, $59.9 \%$ of Latinos residing in the United States were US-born and this number increased to $65.6 \%$ by 2015 (Flores, 2017). Although Latinos who come to the US as adults are more comfortable with Spanish than English, their children, whether US-born or brought to the US at a young age, tend to become English-dominant within a few years of attending school and being immersed with English-speaking peers (Potowski, 2005). These individuals are commonly referred to as heritage speakers of Spanish (HSS) ${ }^{1}$. Since HSS grow up interacting with their parents in Spanish but receive more linguistic input from English, they present a unique opportunity for the study of bilingualism. Heritage speakers generally are more proficient in their parents' language before entering school but then rapidly acquire the language of their peers in elementary school. The linguistic input of the heritage language that these speakers receive is far less than that of monolinguals because exposure is commonly limited to the familial context. Heritage speakers, therefore, have the unique combination of early exposure to a first language like monolingual speakers, but have more exposure to a second language.

Heritage exposure in the home tends to be exclusively oral language. Therefore, many heritage learners want to work on literacy since their reading and writing skills tend to be under-developed in comparison to their listening and speaking abilities (Potowski, 2002; Thompson, 2015). Reading, and to an even greater extent, writing, require metalinguistic awareness. That is, literacy necessitates going beyond understanding the messages conveyed by language; it requires thinking about and analyzing language as an object unto itself. One of the aspects of writing that HSS and their teachers often cite as particularly challenging is the use of accent marks. Spanish has consistent rules for when accent marks should be used but applying these rules depends on being able to identify lexical stress. In a study of applied methods to teach accent rules to HSS, Beaudrie (2017) shows that the aspect of implementing accent rules that HSS found to be the most challenging is determining which syllable in a word is stressed. Of course, identifying a stressed syllable is predicated upon being able to break words into syllables.

1 In this paper, I use the terms 'heritage' and '(early) bilingual' interchangeably. The current most common way to refer to these individuals is as 'heritage' speakers, so I employ this term. However, I agree with Orteguy's (2016) argument that heritage speakers are native speakers and that the ways in which their grammars diverge from those of monolinguals do not mean that their Spanish is deficient as implied by much of the language that linguists use (the term 'heritage' itself as something distinct from native, 'incomplete acquisition', 'attrition', 'English interference', etc.) in descriptions of US Spanish. 
Studies on a variety of language pairs have tested second language learners' syllabification abilities (Benson, 1988; Carlisle, 1991; Hodne, 1985; Sato, 1984; ZárateSández, 2011). These studies show that individuals who acquire a second language as adults do not have native-like intuitions about syllable structure. In these studies, these learners applied the syllable structure of their native language to their second language, resulting in non-native productions. Very little research has been conducted on the syllabification intuitions of heritage speakers. These speakers have a unique linguistic profile. On the one hand, they learn their heritage language from birth and therefore often have intuitions like those of monolingual speakers; on the other hand, these individuals receive more exposure to and formal education in their second language and thus may exhibit transfer from their second language onto their first. Sequences of two vowels provide a useful context to test these bilinguals' syllabification judgements because English and Spanish differ in how they treat these sequences. English phonology prefers the separation of two vowels into separate syllables (hiatus), whereas in Spanish, these sequences are more frequently pronounced together as one syllable (diphthong), with certain exceptions.

The present study considers three different stress patterns with io sequences. The position of lexical stress determines whether these sequences are syllabified in hiatus or diphthong. Generally, a two-vowel sequence in Spanish with a high and non-high vowel is syllabified as a single syllable. Examples (a) and (b) below show words that follow this pattern. If the stress is in another syllable, as in (a), the io sequence forms a diphthong. A diphthong is also pronounced when the stress falls on the $o$ in the $i o$ sequence, as in (b). If the high vowel is stressed, the two-vowel sequence will be pronounced as separate syllables, as in example (c).

a). Diphthongization unstressed $\mathrm{W}$ - io

novio 'boyfriend' ['no.ßjo]

b). Diphthongization of $\mathrm{W}$ with stressed non-high vowel - ió

pidió 'he/she asked for' [pi.' ‘jo]

c). Hiatus of $\mathrm{W}$ with stressed high vowel - ío río ['ri.o]

This study explores HSS's syllabification intuitions of io vowel sequences with the three stress patterns above and compares their performance to that of monolingual 
Spanish speakers and second language speakers of Spanish in the United States whose first language is English. The relationship between language exposure and the metalinguistic task of determining the number of syllables in a word has received very little attention in the literature. This study contributes to the understudied area of bilingual suprasegmental phonology. In terms of application, a better understanding of HSS's phonological awareness is useful for literacy instruction.

\section{Literature Review}

Most research on heritage language has focused on morphological and syntactic similarities and differences between bilingual and monolingual speakers (Rao \& Ronquest, 2015). Until recently, it was assumed that HSS' phonology matched that of monolinguals. A growing body of research, however, shows quantifiable differences between bilingual and monolingual speakers in various aspects of pronunciation (Amengual, 2012; Colantoni, Cuza, \& Mazzaro, 2016; Knightly, Jun, \& Au 2003; Rao, 2015; Robles-Puente, 2014; among others). These differences seem to be largely the result of transfer from the dominant second language onto the heritage language. For example, Ronquest (2013) find that HSS Spanish in the US produce vowels in unstressed syllables that are shorter in duration than do monolingual speakers of Spanish. This is likely due to the influence of English phonology, since durational differences between stressed and unstressed syllables are greater in English than in Spanish (Delattre, 1969). English and Spanish have differences in their consonant systems as well. English has longer voice onset timing (VOT) for voiceless stops $(/ \mathrm{p} /, / \mathrm{t} /, / \mathrm{k} /$ ) than Spanish (Lisker \& Abramson, 1967). Au, Knightly, Jun, and Oh (2002) find that HSS have monolingual-like VOT. However, in a study that controlled for cognates vs. non-cognates, Amengual (2012) finds that HSS produce longer VOT in Spanish words with corresponding English cognates in Spanish words without English cognates. His results show that there is some English influence on heritage speaker pronunciation of words that are shared between the two languages. English voiced stops $(\mathrm{b} /, / \mathrm{d} /, / \mathrm{g} /)$ between vowels have more closure than do the corresponding sounds in Spanish. The results of studies conducted on heritage production of these sounds are mixed. Au et al. (2002) finds HSS to be like monolinguals in their pronunciation of all three stops. Knightley et al. (2003) find the same for $/ b /$ and /d/, but /g/ displayed more closure. Rao (2015) finds no significant differences between monolingual and bilingual speakers for $/ \mathrm{d} /$ and $/ \mathrm{g} /$, but $/ \mathrm{b} /$ was more variable.

Despite these differences between monolingual and heritage pronunciation, segmental knowledge serves HSS well in the classroom. In a corpus study of HSS' spelling mistakes, Beaudrie (2012) finds that heritage writers do well with grapheme use; their 
main difficulty with spelling, accounting for over two thirds of the errors, is with the use of accent marks. While grapheme use depends upon an ability to map individual sounds to letters, being able to correctly place accent marks relies on suprasegmental knowledge. Heritage intuitions of suprasegmental phonological features are just beginning to be explored.

Spanish orthography has a set of rules governing the use of accents; a writer's ability to apply these rules depends upon their metalinguistic knowledge of syllabification and lexical stress. Kim (2015) performed a study on HSS's abilities to perceive and produce contrastive stress with minimal pairs like paso/pasó. She finds that HSS have monolingual-like perception, but their production of paso is inconsistent - they do not always produce the stressed /a/ with a longer duration than the /0/, unlike monolinguals. Heritage participants produce penultimate stress as ultimate (thus pronouncing paso like pasó), as do the second language learners in her study. Kim's finding shows that HSS do not have trouble with auditory comprehension - HSS can hear whether a speaker means 'I pass' (paso) or 'he/she passed' (pasó). However, HSS do not reliably produce this difference in their own speech. This difference in production is in line with Beaudrie's (2017) assertion that the difficulty of correctly placing accent marks has to do with HSS's trouble with producing lexical stress.

Another important aspect of suprasegmental knowledge that has implications for the use of accent marks is syllabification. The test items in Kim's (2015) study have a single vowel in the nucleus of each syllable. The syllabification of these words, therefore, follows the same patterns that would be expected in English. That is, paso, if it were an English word, would be syllabified as /pa.so/, just as in Spanish. Thus, syllabification intuitions are highly likely to be like those of monolinguals and not interfere with the study of lexical stress. Little is known, however, about how HSS perceive syllables in contexts where English and Spanish phonologies diverge. As mentioned in the introduction, English and Spanish differ in their treatment of two-vowel sequences. English tends to separate these sequences into two separate syllables, especially in the case of raising sonority (Davidson \& Erker, 2014; McCarthy, 1993). Spanish, conversely, has a preference to combine the vowels into a single syllable, with exceptions for sequences of two non-high vowels and for sequences with a stressed high vowel (Chitoran \& Hualde, 2007; Hualde \& Prieto, 2002).

Zárate-Sández (2011) looked at syllabification judgements for nine two-vowel sequences ( $<\mathrm{ie}>,<\mathrm{ia}>$, <ai $>,<\mathrm{i} 0>$, $<\mathrm{ua}>,<\mathrm{au}>,<\mathrm{ue}>,<\mathrm{eu}>,<\mathrm{ei}>$ ) in undergraduate second language learners of Spanish ranging from beginning to advanced levels of study. All of the vowel sequences that Zárate-Sández includes in his study are 
diphthongs (according to standard descriptions of Spanish - see Hualde, 2005). His control group of monolingual speakers reports diphthongs $90 \%$ of the time, whereas all three groups of second language learners indicate diphthongs for only $56-59 \%$ of the stimuli. Second language learners are more accurate with two-vowel sequences that have analogous diphthongs in English, which are generally those that have falling sonority. For example, second language learners accurately combine the vowels in words with $<$ ai $>$, like baile ('dance'); the diphthong in the English word right closely resembles the vowel sequence in Spanish. The accuracy rate for sequences with no corresponding diphthong in English, like <io > (35.5\%), is much lower. Zárate-Sández does not explore the effect of stress on dipthongization rates; about half of his stimuli have stress on the diphthongized syllable, but he does not enter this into the analysis.

To date, few studies have examined the syllabification judgements of HSS. Chappell (2018) performed a perception study in which HSS listened to nonce words ending with familiar (-fono) and unfamiliar (-pine) suffixes. She finds that heritage listeners, unlike monolinguals, are less accurate with words with the unfamiliar suffix (-pine) and concludes that HSS rely more heavily on familiar structures than do monolinguals. Two previous studies have examined HSS' syllabification of two-vowel sequences. Shelton, Counselman, and Gutiérrez Palma (2017) look at the effects of cognate status, whether the diphthongs exist as well in English, rising vs. falling diphthongs, and the glide type (palatal vs. velar). They find that each of these factors influences the rate at which HSS syllabify the vowel sequences as diphthongs or hiatus. Heritage participants perform more like monolinguals with words that are not cognates in English, with diphthong sounds that are also existent in English (like the sequence /ai/ in baile 'dance' which is similar to the diphthong in the English word right), with falling diphthongs (which are rare in English), and with velar glides (which are more common in English than palatal glides). In a study of the syllabification of -ear and -iar verbs, Beaton (2020) divides heritage speakers into two groups based on Spanish language exposure and compares their performance to that of monolingual speakers. Overall, neither group of HSS differs significantly from monolinguals. However, the lower-exposure HSS are more affected by the task type than the other groups; they syllabify /ea/ as a diphthong (which is common in colloquial speech) in the reading task significantly more than in the listening task. Chappell (2018), Shelton et al. (2017), and Beaton (2020) do not consider the roles of written accent marks and lexical stress.

Studying io sequences with differing stress patterns makes it possible to observe whether stress placement affects heritage speakers' ability to syllabify. Strong literacy skills go hand in hand with the ability to analyze language itself. Therefore, the task of counting 
syllables, although not predictive of a speaker's language production, does tell us about their metalinguistic intuitions. These intuitions, as discussed above, are important for aspects of writing such as correctly placing accent marks. To account for the fact that heritage speakers are often more adept at processing audio information than written information (Bolger \& Zapata, 2011; Montrul, 2008), participants in the present study complete a task first with written words and then a second task with audio stimuli. This will be explained in greater detail in the methodology section. The research questions for this study are formalized below.

\section{Research Questions}

1) Do HSS perceive syllables with io sequences like monolingual speakers, like second language learners, or does their behavior differ from both groups?

2) Does the stress pattern in io sequences make a difference as to how participants syllabify?

3) Does reading a word vs. listening to a word influence how syllable structure is perceived?

\section{Methodology}

\section{Participants}

The forty monolingual participants for this study are college students from the Universidad de Querétero. All were born and raised in Mexico. The heritage and second language learners were recruited from universities across the United States. Most of the heritage speakers (49) have Mexican parents; a few heritage participants (5) are of Central American descent. The fifty-one second language learners were at the intermediate level in their third to fifth semester of college Spanish. After completing the syllabification tasks, all participants filled out a demographic questionnaire, which was used to categorize participants as monolingual, heritage, or L2. This questionnaire was based upon Montrul's Bilingual Background Questionnaire (2012). Participants indicated the city and country of their birth, where they currently live, where their parents are from, the language(s) spoken at home while they were growing up, a self-rating of speaking and listening abilities in Spanish and English, and how old they were when they started frequently hearing English and Spanish respectively. The demographic questionnaire is included in Appendix A. 
Participants who described their childhood home language as 'Spanish only' and who had spent birth to age 18 in Mexico were classified as monolingual speakers. Second language learners grew up speaking 'English only' and were born and raised in the United States. Heritage homes could be 'Spanish only,' 'mostly Spanish,' or 'an equal mix of Spanish and English.' All the heritage participants began to learn Spanish in infancy and are sequential bilinguals, meaning that they learned Spanish before they learned English. They rated themselves highly on both their English and Spanish speaking and listening skills (fours and fives on a scale of 1-5). Some heritage participants were born outside of the United States and came with their parents as small children or in their early teens. Others were born and raised in the US. In still other cases, heritage participants were born in the US but had spent significant portions of their lives in their parents' home countries. ${ }^{2}$

\section{Tasks}

Participants completed syllabification tasks on an online Qualtrics survey. The survey had two parts - a reading task and a listening task. In the first part, participants saw a word and were asked to indicate the number of syllables in the word and then to show how they would divide the stimulus into syllables. Participants performed this task for 8 target stimuli and 15 distractor items. Figure 1 below shows an example with the distractor item abeja 'bee.'

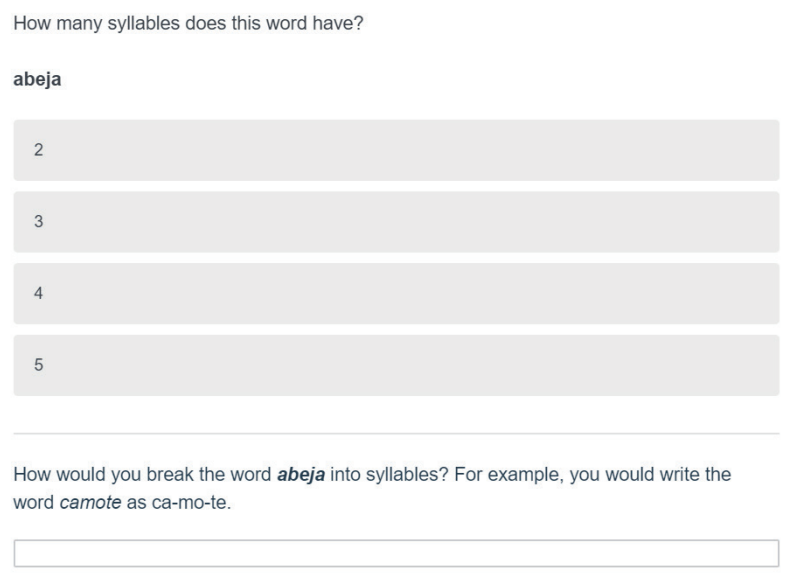

Figure 1. Reading task.

2 Obviously, the heritage individuals in this study do not form a homogenous group. This is typical of this population. Because of the wide range of language exposure backgrounds, these participants were initially divided into two distinct groups in the data analysis phase based upon the amount of time spent outside of the United States. However, the two groups did not display statistically significant differences from each other, so they were ultimately grouped together. 
After completing the reading task, participants moved on to the listening task. This second half of the survey was identical to the first except the stimuli were presented as sound clips. The stimuli were read by a phonetically-trained native speaker of Spanish from Guadalajara, Mexico. Participants performed this task for 8 target stimuli and 13 distractor items. See Figure 2 below for a screenshot from the listening portion of the task.

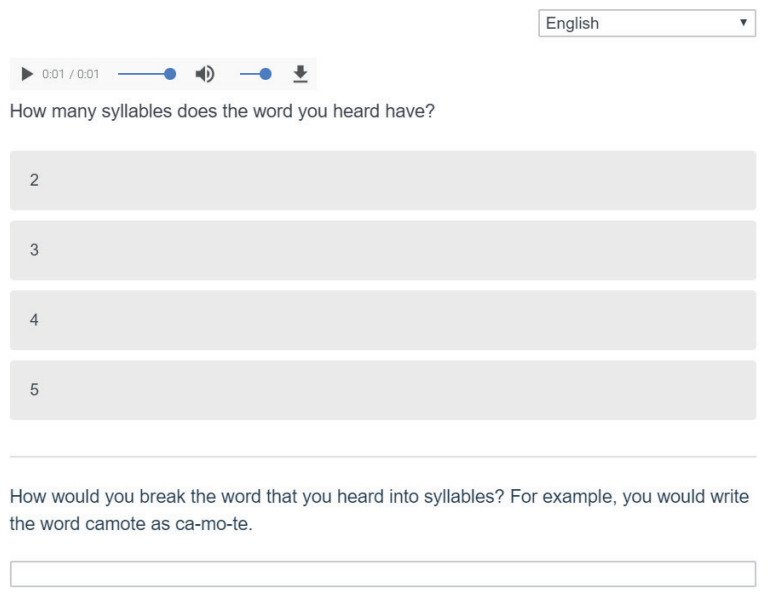

Figure 2. Listening task.

The target stimuli with io sequences in each task are listed in Table 1 below. The stimuli selected were two or three syllable words with open syllable structure (i.e. none of the syllables in these words have codas). Each of the three stress patterns is represented in both the reading and listening tasks. That is, each task contains a set of words with stress on the $i$ of the io syllable, a set with stress on the $o$ of the $i o$ syllable, and a set with stress on the syllable preceding the io syllable. A short training segment was presented to participants before both the reading and listening tasks. Within the tasks, the target items were presented in a random order and distractor stimuli with single-vowel nuclei were included in both tasks.

Table 1. Target stimuli.

\begin{tabular}{|c|c|c|}
\hline $\begin{array}{c}\text { Hiatus of VV with stressed high vowel - } \\
\text { ío category }\end{array}$ & Reading Task & Listening Task náo \\
\hline $\begin{array}{c}\text { Diphthongization of VV with stressed } \\
\text { non-high vowel - ió category }\end{array}$ & $\begin{array}{c}\text { vació, debió, } \\
\text { nació }\end{array}$ & judío, rocío \\
\hline $\begin{array}{c}\text { Diphthongization unstressed VV - io } \\
\text { category }\end{array}$ & novio, tedio, julio & labio, medio, folio \\
\hline
\end{tabular}




\section{Analysis}

The dependent variable for the analysis was the number of syllables reported by participants minus the number that the word would have with the $i o$ sequence in hiatus. For example, for the word novio 'boyfriend', participants either correctly indicated two syllables (no.vio) or incorrectly divided the two vowel sequence and reported that they believed the word had three syllables (no.vi.o). If the participant reported two syllables, the difference between the reported number (2) and the number in hiatus (3) would be -1 . If the participant reported three syllables, the difference would be zero. Using the difference between the hiatus number and the reported number makes comparing the three different stress patterns more straightforward. Since two of the $i o$ vowel sequences (stress on $o$, stress on previous syllable) are prescriptively diphthongized and the other stress pattern in this study (stress on $i$ ) is prescribed as hiatus, the difference metric was used to compare the three stress patterns. Subtracting the number of syllables the word would have if the vowel sequence were in hiatus was an arbitrary decision - the analysis would work equally well using the diphthongized syllable count as the subtracted number.

\section{Results}

Table 2 below presents the percentage response of hiatus for each stress pattern (accent on $i$, accent on $o$, atonic) and for each task (reading and listening). These descriptive statistics have to be taken with a grain of salt - they do not account for differences between individual participants or stimuli.

Table 2. Percentage hiatus by stress pattern and task for each speaker category.

\begin{tabular}{|c|c|c|c|c|c|c|}
\hline & \multicolumn{2}{|c|}{ Stress on $i$} & \multicolumn{2}{c|}{ Stress on o } & \multicolumn{2}{c|}{ Atonic io } \\
\hline & Reading & Listening & Reading & Listening & Reading & Listening \\
\hline \multirow{2}{*}{ Monolingual } & $58 \%$ & $76 \%$ & $32 \%$ & $22 \%$ & $16 \%$ & $15 \%$ \\
Heritage & $53 \%$ & $83 \%$ & $43 \%$ & $21 \%$ & $25 \%$ & $29 \%$ \\
L2 & $71 \%$ & $82 \%$ & $63 \%$ & $46 \%$ & $59 \%$ & $52 \%$ \\
\hline
\end{tabular}

A mixed effects regression model follows in Table 3. The independent variables in the analysis were speaker category (monolingual, heritage, second language), stimuli 
mode (listening vs. reading task), and stress pattern (stress on $i$, stress on $o$, atonic). Interactions between these variables were also entered into the statistical model. Participant and individual target stimuli were considered as random effects. Positive estimates indicate a greater use of hiatus and negative estimates correspond with more diphthong judgements. Significant findings are bolded. The intercept is monolingual participants with the accent on $i$ pattern in the reading task.

Table 3. Linear mixed effects regression model.

\begin{tabular}{|l|l|l|l|l|}
\hline & Estimate & $\begin{array}{l}\text { Standard } \\
\text { Error }\end{array}$ & $\mathrm{t}$-Value & $\mathrm{p}$-value \\
\hline (Intercept) & $\mathbf{- 4 . 1 8 8 \mathrm { e } - 0 1}$ & $\mathbf{5 . 4 5 9 e - 0 2}$ & $\mathbf{- 7 . 6 7 2}$ & $\mathbf{2 . 4 3 e - 1 3}$ \\
\hline $\begin{array}{l}\text { Speaker Category } \\
\text { Heritage }\end{array}$ & $-4.786 \mathrm{e}-02$ & $7.137 \mathrm{e}-02$ & -0.671 & 0.502951 \\
L2 & $8.547 \mathrm{e}-02$ & $7.252 \mathrm{e}-02$ & 1.179 & 0.239498 \\
\hline $\begin{array}{l}\text { Stress Pattern } \\
\text { o accent } \\
\text { atonic }\end{array}$ & & & & \\
\hline Task Type & $\mathbf{- 2 . 6 0 7 e - 0 1}$ & $\mathbf{5 . 3 7 5 e - 0 2}$ & $\mathbf{- 4 . 8 5 0}$ & $\mathbf{1 . 3 2 e - 0 6}$ \\
listening & $\mathbf{- 4 . 1 8 8 e - 0 1}$ & $\mathbf{4 . 8 0 7 e - 0 2}$ & $\mathbf{- 8 . 7 1 2}$ & $<\mathbf{2 e - 1 6}$ \\
\hline $\begin{array}{l}\text { Interaction: } \text { Speaker } \\
\text { Category and Stress } \\
\text { Pattern }\end{array}$ & & & & \\
Heritage: 0 accent & $1.637 \mathrm{e}-01$ & $7.140 \mathrm{e}-02$ & 2.553 & $\mathbf{0 . 0 1 0 7 6 1}$ \\
L2: o accent & $1.823 \mathrm{e}-01$ & $6.285 \mathrm{e}-02$ & 2.228 & $\mathbf{0 . 0 2 5 9 9 1}$ \\
Heritage: atonic & $1.400 \mathrm{e}-01$ & $6.386 \mathrm{e}-02$ & $\mathbf{5 . 3 3 0}$ & $\mathbf{1 . 0 9 e - 0 7}$ \\
L2: atonic & $3.404 \mathrm{e}-01$ & & $\mathbf{5 . 1 5 1}$ & $\mathbf{0 . 0 0 1 6 4 8}$ \\
\hline $\begin{array}{l}\text { Interaction: } \text { Speaker } \\
\text { Category and Task }\end{array}$ & & & & \\
$\begin{array}{l}\text { Heritage: listening } \\
\text { L2: listening }\end{array}$ & $1.263 \mathrm{e}-01$ & $7.095 \mathrm{e}-02$ & 1.779 & 0.075332 \\
\hline
\end{tabular}




\begin{tabular}{|l|l|l|l|l|}
\hline $\begin{array}{l}\text { Interaction: } \text { Stress } \\
\text { Pattern and Task }\end{array}$ & & & & \\
o accent: listening & $\mathbf{- 2 . 7 3 3 e - 0 1}$ & $\mathbf{7 . 6 8 4 e - 0 2}$ & $\mathbf{- 3 . 5 5 7}$ & $\mathbf{0 . 0 0 0 3 8 3}$ \\
atonic: listening & $\mathbf{- 1 . 8 5 8 e - 0 1}$ & $\mathbf{7 . 2 6 9 e - 0 2}$ & $\mathbf{- 2 . 5 5 6}$ & $\mathbf{0 . 0 1 0 6 6 0}$ \\
\hline $\begin{array}{l}\text { Interaction: Speaker } \\
\text { Category, Stress }\end{array}$ & & & & \\
Pattern, Task & & & & \\
Heritage: $\mathbf{0}$ accent: & $\mathbf{- 2 . 4 8 4 e - 0 1}$ & $\mathbf{1 . 0 0 3 e - 0 1}$ & $\mathbf{- 2 . 4 7 7}$ & $\mathbf{0 . 0 1 3 3 2 4}$ \\
listening & $-5.595 \mathrm{e}-02$ & $1.019 \mathrm{e}-01$ & -0.549 & 0.582861 \\
L2: 0 accent: listening & $-7.336 \mathrm{e}-02$ & $9.489 \mathrm{e}-02$ & -0.773 & 0.439586 \\
Heritage: atonic: & $-5.707 \mathrm{e}-02$ & $9.657 \mathrm{e}-02$ & -0.591 & 0.554617 \\
listening & & & & \\
L2: atonic: listening & & & & \\
\hline
\end{tabular}

\section{Accent on $i$}

Vacio ('empty') and judio ('Jew') are examples of Spanish words with stress on a high vowel in a two-vowel sequence. Unlike the other two stress patterns in this study (accent on $o$ and atonic), these sequences are syllabified as separate syllables. As stated above, the intercept in the regression model is stress on $i$, monolingual speakers, reading task. The insignificant p-values for the three groups in the speaker category main effect indicates that the heritage and second language learners do not behave differently from monolinguals in the listening task. The main effect for task type shows that monolingual speakers perform differently in the listening task than the reading task for this stress pattern; they syllabify in hiatus more in the listening task. Hence, they are more accurate in the listening task than in the reading task. The lack of significant effects for the interaction between speaker category and the reading task shows that the behavior of the other speaker groups is as would be expected for their groups in that task. The HSS and the second language learners, therefore, also assign more syllables in the listening task than the reading task, and their responses do not differ from those of monolinguals.

\section{Accent on o}

Words like vació ('emptied') and pidió ('asked for') feature stress on the nonhigh vowel of the two-vowel sequence and thus are prescriptively indicated as diphthongs. 
The main effect for the accent on $o$ stress pattern is significant and the estimate is -0.26 . This means that monolingual speakers assign fewer syllables to ió words than io words in the reading context. The significant findings for the interaction effect for both speaker groups and $o$ accent both have positive estimates. This means that HSS and L2s have more similar rates of hiatus across the $i$ accent and $o$ accent categories than do monolingual speakers

The negative estimate for the interaction effect for $o$ accent and the listening task shows that monolingual speakers assign significantly fewer syllables in the listening task than the reading task. The significant effect for the three-way interaction term between the heritage group, $o$ accent, and the reading task means that heritage speakers are particularly sensitive to task type for this stress pattern. This is evident in the descriptive statistics; monolinguals only differ $10 \%$ between the two tasks (22\% hiatus in the listening task and $32 \%$ in the reading task) whereas heritage speakers have more than double the 'incorrect' hiatus response in the reading task. Unlike in the reading task, HSS do not significantly differ from monolinguals in the listening task. Although the L2 group improves their performance in the listening task, the improvement is less dramatic than that of the heritage group.

The t-tests with Tukey's multiple comparisons adjustment below in Tables 4 and 5 calculate the estimates from the regression model and compare them. This clarifies the differences in group behavior when presented with $i$ accent vs. $o$ accent stimuli. In the reading task, only monolinguals tend to follow the prescriptive rule for $i$ accent words to be in hiatus and $o$ accent to feature diphthongs. Thus, only monolinguals display a significant difference between the two accent patterns in the reading task, as shown in Table 4 below. In the audio task (Table 5), however, all three groups successfully distinguish the hiatus from the diphthong, assigning significantly more syllables to the $i$ accent pattern.

Table 4. T-test results comparing $i$ accent and 0 accent patterns in the reading task

\begin{tabular}{|l|l|l|l|l|l|}
\hline & Estimate & $\begin{array}{l}\text { Standard } \\
\text { Error }\end{array}$ & $\begin{array}{l}\text { Degrees of } \\
\text { Freedom }\end{array}$ & t-ratio & p value \\
\hline $\begin{array}{l}\text { Monolingual } \\
\text { Heritage } \\
\text { Second Language }\end{array}$ & $\mathbf{0 . 2 6 0 6 8}$ & $\mathbf{0 . 0 5 3 7}$ & $\mathbf{2 1 3 3}$ & $\mathbf{4 . 8 5 0}$ & $\mathbf{0 . 0 0 0 2}$ \\
0.09697 & 0.0453 & 2133 & 2.143 & 0.7908 \\
& 0.07843 & 0.0470 & 2133 & 1.669 & 0.9722 \\
\hline
\end{tabular}


Table 5. T-test results comparing $i$ accent and $o$ accent patterns in the listening task

\begin{tabular}{|l|l|l|l|l|l|}
\hline & Estimate & $\begin{array}{l}\text { Standard } \\
\text { Error }\end{array}$ & $\begin{array}{l}\text { Degrees of } \\
\text { Freedom }\end{array}$ & t-ratio & p value \\
\hline $\begin{array}{l}\text { Monolingual } \\
\text { Heritage } \\
\text { Second Language }\end{array}$ & $\mathbf{0 . 5 3 3 9 8}$ & $\mathbf{0 . 0 5 4 9}$ & 2134 & 9.725 & $<.0001$ \\
& $\mathbf{0 . 6 1 8 6 3}$ & 0.0458 & 2134 & 13.498 & $<.0001$ \\
& $\mathbf{0 . 4 0 7 6 8}$ & 0.0476 & 2134 & 8.570 & $<.0001$ \\
\hline
\end{tabular}

\section{Atonic io}

Stimuli such as novio ('boyfriend') and medio ('middle') feature the io sequence in a post-tonic syllable. Atonic two-vowel sequences are prescriptively syllabified as diphthongs. The main effect for the atonic stress pattern is significant and the estimate is negatively valanced $(-0.42)$. This shows that monolinguals follow the prescriptive norms and thus are less likely to syllabify in hiatus for the atonic pattern than for the $i$ accent pattern. The two-way interactions for the heritage (0.14) and L2 (0.34) groups are significant and positive, which means that they syllabify in hiatus more than monolingual speakers. When compared to their rates of hiatus for $i$ accent words, heritage speakers, like monolinguals, differentiate the two patterns, assigning significantly more syllables to $i$ accent words than atonic words. Second language learners, however, fail to distinguish the two patterns in the reading task. See Table 6 below.

Unlike with the other two syllable types, there is not a significant difference for monolinguals between the reading and listening tasks. The interaction effect for the atonic pattern in the listening context is significant, but the estimate $(-0.1858)$ essentially cancels out the main effect for the listening task (0.1715). This can be seen in the percentages of hiatus for monolinguals in Table 2 above (16\% in reading task and 15\% in listening task). The heritage and L2 groups also do not differ in their responses between tasks. This is intuitive from the percentages for each group across tasks (for HSS 25\% in the reading task and 29\% in the listening task; for L2, 59\% and $52 \%$ respectively). All three groups assign more syllables to the $i$ accent audio stimuli than the atonic audio stimuli. 
Table 6. T-test results comparing $i$ accent and atonic patterns in the reading task

\begin{tabular}{|l|l|l|l|l|l|}
\hline & Estimate & $\begin{array}{l}\text { Standard } \\
\text { Error }\end{array}$ & $\begin{array}{l}\text { Degrees of } \\
\text { Freedom }\end{array}$ & t-ratio & p value \\
\hline $\begin{array}{l}\text { Monolingual } \\
\text { Heritage }\end{array}$ & $\mathbf{0 . 4 1 8 8 0}$ & $\mathbf{0 . 0 4 8 1}$ & $\mathbf{2 1 3 3}$ & $\mathbf{8 . 7 1 2}$ & $<.0001$ \\
Second & $\mathbf{0 . 2 7 8 7 9}$ & $\mathbf{0 . 0 4 0 5}$ & $\mathbf{2 1 3 3}$ & $\mathbf{6 . 8 8 7}$ & $<.0001$ \\
Language & 0.07843 & 0.0420 & 2133 & 1.866 & 0.9241 \\
\hline
\end{tabular}

Table 7. T-test results comparing $i$ accent and atonic patterns in the listening task

\begin{tabular}{|l|l|l|l|l|l|}
\hline & Estimate & $\begin{array}{l}\text { Standard } \\
\text { Error }\end{array}$ & $\begin{array}{l}\text { Degrees of } \\
\text { Freedom }\end{array}$ & t-ratio & $p$ value \\
\hline $\begin{array}{l}\text { Monolingual } \\
\text { Heritage } \\
\text { Second Language }\end{array}$ & 0.60459 & 0.0545 & 2134 & 11.089 & $<.0001$ \\
& 0.32129 & 0.0477 & 2134 & 6.736 & $<.0001$ \\
\end{tabular}

Since $i$ accent is in the intercept, the other two stress patterns are compared to it and not to each other in the regression model. Post-hoc t-tests with Tukey's adjustment were performed to compare the $o$ accent and atonic patterns to each other. The results are shown in Tables 8 and 9 below. In the listening task (Table 9), each participant group has insignificant differences between the two contexts. That is, they respond to $o$ accent stimuli in the same way that they respond to atonic stimuli. In the reading task (Table 8), monolingual and second language learners also do not respond significantly differently to these two stress patterns. Heritage speakers, however, are less accurate with $o$ accent stimuli than atonic stimuli in the reading task; they assign more hiatus to $o$ accent words than with atonic words.

Table 8. T-test results comparing $o$ accent and atonic patterns in the reading task

\begin{tabular}{|l|l|l|l|l|l|}
\hline & Estimate & $\begin{array}{l}\text { Standard } \\
\text { Error }\end{array}$ & $\begin{array}{l}\text { Degrees of } \\
\text { Freedom }\end{array}$ & t-ratio & p value \\
\hline $\begin{array}{l}\text { Monolingual } \\
\text { Heritage } \\
\text { Second } \\
\text { Language }\end{array}$ & 0.15812 & 0.0537 & 2133 & 2.942 & 0.2303 \\
$\mathbf{0 . 1 8 1 8 2}$ & $\mathbf{0 . 0 4 5 3}$ & $\mathbf{2 1 3 3}$ & $\mathbf{4 . 0 1 7}$ & $\mathbf{0 . 0 0 7 6}$ \\
& 0.00000 & 0.0470 & 2133 & 0.000 & 1.0000 \\
\hline
\end{tabular}


Table 9. T-test results comparing 0 accent and atonic patterns in the listening task

\begin{tabular}{|l|l|l|l|l|l|}
\hline & Estimate & $\begin{array}{l}\text { Standard } \\
\text { Error }\end{array}$ & $\begin{array}{l}\text { Degrees of } \\
\text { Freedom }\end{array}$ & t-ratio & $p$ value \\
\hline $\begin{array}{l}\text { Monolingual } \\
\text { Heritage }\end{array}$ & 0.07061 & 0.0487 & 2134 & 1.449 & 0.9937 \\
Second Language & -0.08070 & 0.0410 & 2134 & -1.970 & 0.8831 \\
& -0.08639 & 0.0425 & 2134 & -2.034 & 0.8526 \\
\hline
\end{tabular}

1). Do HSS perceive syllables with io sequences like monolingual speakers, like second language learners, or does their behavior differ from both groups?

Their performance lies somewhere between monolinguals and second language learners. In the case of the stress on $i$ pattern, which is prescriptively syllabified in hiatus, neither HSS nor L2 participants differ from monolinguals. Heritage speakers reported hiatus more than monolinguals in the two diphthongization stress patterns (accent on $o$ and atonic - see between interactions speaker category and stress pattern in Table 3). However, their intuitions are less divergent from monolinguals than those of second language learners.

2). Does the stress pattern in io sequences make a difference as to how participants syllabify?

This depends upon the speaker group. For the reading task, monolingual and heritage speakers are influenced in different ways by written accents. Second language learners do not seem to be influenced by the presence or absence of written accents; their hiatus rates are similar across the three stress patterns. Monolingual speakers' intuitions align with prescriptive descriptions of the patterns in both tasks; $i$ accent words are in hiatus whereas $o$ accent and atonic words have diphthongs (see main effects for stress pattern in Table 3). It appears that in the reading task heritage speakers interpret written accents as indications of hiatus and therefore do not significantly differ in their treatment of $i$ accent and $o$ accent but do correctly assign more diphthongs to atonic (which has no written accent) than $i$ accent. These effects are most clearly represented by the comparisons in Tables 4 and 6 . The comparison of $o$ accent and atonic is consistent with this hypothesis, heritage speakers display significantly more hiatus judgments with $o$ accent than with atonic. See Table 8. The listening task is addressed in question 3 below.

3). Does reading a word vs. listening to a word influence how syllable structure is perceived? 
For $i$ accent and $o$ accent, yes. For atonic, no. All three groups are more accurate in the listening task than the reading task for $i$ accent and $o$ accent. That is, they use more hiatus for $i$ accent in the listening task than the reading task (see main effect for listening task) and they report less hiatus for $o$ accent in the listening task than the reading task (see interaction between $o$ accent and listening task). The interaction effect for the atonic listening task is significant, but this simply indicates that participants behave differently in the atonic context than the $i$ accent context. The estimate for the interaction between atonic and listening (-0.19) cancels out the main effect for the listening task $(0.17)$, resulting in insignificant differences between the reading and listening tasks in the atonic context.

\section{Discussion and Conclusions}

The experimental tasks in this study involve dividing words into syllables, which is not a communicative activity. Thus, we cannot expect the results to necessarily be in line with how participants speak. Metalinguistic tasks like this one, however, provide valuable insight as to how speakers might perform in other metalinguistic pursuits, such as correctly placing accent marks through an understanding of rules rather than rote memorization. The monolingual Spanish speakers in this study did not perform perfectly. With the three stress patterns analyzed here, they correctly syllabified the vowel sequence $58 \%, 68 \%$, and 84\% correctly in the reading task for $i$ accent, $o$ accent, and atonic contexts respectively. Previous studies on syllabification with reading tasks (Beaton, 2020; Face \& Alvord, 2004; Chitoran \& Hualde, 2007; Shelton et al., 2017) also find that monolingual speakers do not perform at ceiling. This does not by any means indicate that speakers of Spanish stray from descriptions of Spanish syllabification (such as that of Hualde, 2005) in their speech production.

In the listening task, participants perform better with $i$ accent and $o$ accent words than they did in the reading task. Unlike the two stress patterns with written accents, there was no difference in accuracy across tasks for the atonic context. One explanation for this effect is that it is easier to hear diphthong/hiatus contrast in stressed syllables. Since the $i$ accent and $o$ accent words carry stress within the vowel sequence, listeners improve their performance in the listening task. Since atonic words have stress in the syllable before the W sequence, the listening task does not help their performance.

The better performance in the listening task than the reading task is clear for all three participant groups, but it is most prominent for the HSS group. Heritage performance differs from that of monolinguals in the reading task but not in the listening task. As mentioned above regarding monolinguals, the results of an artificial task such 
as this one do not necessarily reflect how participants actually speak. Since heritage speakers generally have little practice with written language, task effects are more likely to be even stronger for these speakers. Thus, we cannot conclude that HSS differ from monolinguals in their actual pronunciation of these words, especially in a naturalistic context. Otheguy (2016), in his critique of studies on this population, makes the point that HSS performance in metalinguistic tasks does not reflect their underlying grammar:

These studies are undermined by the strong possibility that, quite independently of the feature under investigation, literacy itself may be a prerequisite for the accurate production of such judgments (Bialystok \& Ryan, 1985; Birdsong, 1989). Particularly relevant is the greater ability by literates to objectify language (Bialystok, 1986) and the strong possibility that this, and not anything related to actual speech or underlying mental grammar, is the explanation for the much greater success of literate home-country controls in metalinguistic tasks.

Otheguy argues that linguists are mistaken to use the results of non-naturalistic experimental tasks to prove that these individuals are in some way not native speakers of a language that they learned in infancy. Along these lines, I propose viewing results such as those presented in this study to inform pedagogical practices, but not as proof of anything lacking about the linguistic skills of these individuals. Heritage participants in this study tended to assume that written accent marks indicate hiatus. While HSS may indeed differ from monolinguals in their production of lexical stress (as Kim, 2015 and Beaudrie, 2017 find - see literature review above), the findings from this study suggest that their difficulty with accent marks in their writing might have more to do with their (mis)understanding about the purpose of accent marks than their underlying grammar. Addressing this in the classroom could help improve literacy outcomes. Also, their strong performance in the listening task in this study underscores the importance of utilizing audio teaching tools whenever possible. Many textbooks now have online components with recordings accompanying readings and vocabulary words. Heritage students should be especially encouraged to use these resources.

\section{References}

Amengual, M. (2012). Interlingual influence in bilingual speech: Cognate status effect in a continuum of bilingualism. Bilingualism: Language and Cognition, 15(3), 517-530. https://doi.org/10.1017/\$1366728911000460

Au, T. K.-F., Knightly, L. M., Jun, S.-A., \& Oh, J. S. (2002). Overhearing a language during childhood. Psychological Science, 13(3), 238-243. https://doi.org/10.1111/1467-9280.00444 
Beaton, M.E. (2020). Heritage Spanish Speakers' Syllabification of -ear and -iar Verbs. Heritage Language Journal 17(1). https://doi.org/10.46538/hlj.17.1.2

Benson, B. (1988). Universal preference for the open syllable as an independent process in interlanguage phonology. Language Learning 38, 221-242. https://doi. org/10.1111/j.1467-1770.1988.tb00410.x

Beaudrie, S. M. (2012). A corpus-based study on the misspellings of Spanish heritage learners and their implications for teaching. Linguistics and Education 23, 135-144. https://doi. org/10.1016/j.linged.2011.09.001

Beaudrie, S.M. (2017). The Teaching and Learning of Spelling in Spanish Heritage Language Classroom: Mastering Written Accent Marks. Hispania 100(4), 596-611. https://doi. org/10.1353/hpn.2017.0101

Bialystok, E. \& E.B. Ryan. (1985). Toward a Definition of Metalinguistic Skill. Merrill-Palmer Quarterly 31, 229-251.

Bialystok, E. (1986). Factors in the growth of linguistic awareness. Child Development 57(2), 498-510. https://doi.org/10.2307/1130604

Birdsong, D. (1989). Metalinguistic performance and interlinguistic competence. New York: Springer. https://doi.org/10.1007/978-3-642-74124-1

Bolger, P.A. \& G.C. Zapata. (2011). Psycholinguistic Approaches to Language Processing in Heritage Speakers. Heritage Language Journal 8(1), 1-27.

Carlisle, R. (1991). The influence of environment on vowel epenthesis in Spanish/English interphonology. Applied Linguistics 12, 76-95. https://doi.org/10.1093/applin/12.1.76

Chappell, W. (2018). The role of lexical associations and overgeneralizations in heritage Spanish perception. Heritage Language Journal 15(2), 151-172. https://doi.org/10.46538/ hlj.15.2.1

Chitoran, I., \& Hualde, J.I. (2007). From hiatus to diphthong: The evolution of vowel sequences in Romance. Phonology, 24(1), 37-75. https://doi.org/10.1017/S095267570700111X

Colantoni, L., Cuza, A., \& Mazzaro, N. (2016). Task-related effects in the prosody of Spanish heritage speakers and long-term immigrants. In M.E. Armstrong, N. Henriksen, \& M. del Mar Vanrell (Eds.), Intonational grammar in Ibero-Romance: Approaches across linguistic subfields (pp. 1-24). Amsterdam: John Benjamins Publishing Company. https://doi. org/10.1075/ihll.6.01col

Davidson, L., \& Erker, D. (2014). Hiatus resolution in American English: The case against glide insertion. Language, 90(2), 482-514. https://doi.org/10.1353/lan.2014.0028 
Delattre, P. (1969). An acoustic and articulatory study of vowel reduction in four languages. International Review of Applied Linguistics in Language Teaching 7(4), 295-325. https:// doi.org/10.1515/iral.1969.7.4.295

Flores, A. (2017, September 18). How the U.S. Hispanic population is changing. Pew Research Center. (2018, January 2018). Retrieved from https://www.pewresearch.org/facttank/2017/09/18/how-the-u-s-hispanic-population-is-changing/

Hodne, B. (1985). Yet another look at interlanguage phonology: The modification of English syllable structure by native speakers of Polish. Language Learning 35, 405-22. https://doi. org/10.1111/j.1467-1770.1985.tb01084.x

Kim, J.Y. (2015). Perception and production of Spanish lexical stress by Spanish heritage speakers and English L2 learners of Spanish. In E. Willis, P.M. Butragueño, \& E.H. Zendejas (Eds.), Selected Proceedings of the 6th Conference on Laboratory Approaches to Romance Phonology, (pp. 106-128). Somerville, MA: Cascadilla Proceedings Project.

Hualde, J. (2005). Sounds of Spanish. New York: Cambridge University Press. https://doi. org/10.1515/ling.2002.010

Hualde, J.I., \& Prieto, M. (2002). On the diphthong/hiatus contrast in Spanish: Some experimental results. Linguistics, 40, 217-234.

Knightly, L.M., Jun, S.A., \& Au, T. K.-F (2003). Production benefits of childhood overhearing. Journal of the Acoustical Society of America 114, 465-474. https://doi.org/10.1121/1.1577560

Lisker, L. \& A. Abramson. (1967). Voice onset time in English stops. Language and Speech 10(1),1-28. https://doi.org/10.1177/002383096701000101

McCarthy, J.J. (1993). A case of surface constraint violation. Canadian Journal of Linguistics 38, 169-195. https://doi.org/10.1017/S0008413100014730

Montrul, S. (2008). Incomplete acquisition in bilingualism. Re-examining the age factor. Amsterdam: John Benjamins. https://doi.org/10.1075/sibil.39

Montrul, S. (2012). Bilingual background questionnaire for Spanish/English speakers. Available at http://www.nhlrc.ucla.edu/data/questionnaires.asp

Otheguy, R. (2016). The linguistic competence of second-generation bilinguals: A critique of “incomplete acquisition”. In C. Tortora, M. den Dikken, I. L. Montoya, \& T. O’Neill (Eds.). https://doi.org/10.1075/rllt.9.16oth

Romance Linguistics 2013: Selected papers from the 43rd Linguistic Symposium on Romanc eLanguages (LSRL), New York, 17-19 April, 2013, 301-319. Amsterdam: John Benjamins. 
Potowski, K. (2002). Experiences of Spanish heritage speakers in university foreign language courses and implications for teacher training. ADFL Bulletin 33, 35-42. https://doi. org/10.1632/adfl.33.3.35

Potowski, K. (2005). La enseñanza del español a los hablantes nativos. Madrid:ArcoLibros.

Rao, R. (2015). Manifestations of /bdg/ in heritage speakers of Spanish. Heritage Language Journal 12(1), 48-74.

Rao, R. \& R. Ronquest. (2015). The heritage Spanish phonetic/phonological system: Looking back and moving forward. Studies in Hispanic and Lusophone Linguistics 8(2), 403-414. https://doi.org/10.1515/shll-2015-0016

Robles-Puente, S. (2014). Prosody in contact: Spanish in Los Angeles (Unpublished doctoral dissertation). The University of Southern California, Los Angeles, CA.

Ronquest, R. (2013). An acoustic examination of unstressed vowel reduction in heritage Spanish. In C. Howe, S.E. Blackwell, \& M.L. Quesada (Eds.), Selected Proceedings of the 15th Hispanic Lingusitics Symposium (pp. 157-171). Somerville, MA: Cascadilla Proceedings Project.

Sato,C. (1984).Phonological processes insecondlanguage acquisition:Anotherlookatinterlanguage syllable type. Language Learning 34, 43-57. https://doi.org/10.1111/j.1467-1770.1984. tb00351.x

Shelton M., Counselman, D. and Gutiérrez Palma, N. (2017). Metalinguistic Intuitions and Dominant Language Transfer in Heritage Spanish Syllabification. Heritage Language Journal 14(3), 288-306.

Thompson, G.L. 2015. Understanding the heritage language student: Proficiency and placement. Journal of Hispanic Higher Education 14(1), 82-96. https://doi. org/10.1177/1538192714551277

U.S. Census Bureau (2018). Hispanic Heritage Month 2018. Retrieved from https://www.census. gov/newsroom/facts-for-features/2018/hispanic-heritage-month.html

Zárate-Sández, G. (2011). Speakers' intuitions about L2 syllable structure: Diphthong vs. hiatus resolution in Spanish by English-speaking learners. In E. Voss, S.J.D. Tai, \& Z. Li (Eds.), Selected Proceedings of the 2009 Second Language Research Forum (pp. 164-181). Somerville, MA: Cascadilla Proceedings Project. 